\title{
THE SUB-ANTARCTIC ISLANDS OF NEW ZEALAND
}

New Zealand's desolate sub-Antarctic islands have been handed back to nature. The five island groups that have a deservedly bitter reputation for shipwreck and privation have recently been declared " reservations for the preservation of flora and fauna ". If lessons of history are heeded they will most probably stay that way.

To-day only the Campbell Islands are inhabited (by a meteorological and scientific station team) but the groups have seen sealers and settlements in the past, and many stories are told of shipwrecked sailors spending long years pecking a living from the shores while awaiting rescue.

The island groups consist of the Bounty Islands, a cluster of small rocky islets at $47^{\circ} \mathrm{S}$. latitude, the craggy Snares at $48^{\circ} \mathrm{S}$., the barren uplands of the Antipodes $\left(49^{\circ} \mathrm{S}\right.$.), the 235 square miles of Auckland Islands $\left(51^{\circ} \mathrm{S}\right.$.), and the Campbell Islands, at $52^{\circ}$, the last New Zealand outpost on the route to the Antarctic.

\section{FORBIDDING REGION}

Though the islands are only as far from the equator as parts of Scotland, their isolation and exposure to the Antarctic weather system make them a forbidding region. However, they are the home of millions of sea birds, and some land varieties, rare or even vanished from the New Zealand coast.

Considerable scientific value has been placed on these islands and for several years interested people have lobbied for the above extensions to the Auckland and Campbell Islands nature reserves.

Now they will be virtually closed to man in the interests of maintaining preserves of Antarctic and sub-Antarctic birds and plants. In this way it is hoped to keep from the shores vermin and predatory animals which might destroy the bountiful bird life or cause disastrous erosion.

\section{Big Toll of Lives}

Since the islands were first discovered by explorers following Captain James Cook, this region has taken a big toll of lives and has earned a reputation as one of the most bleak in the world. Sealers and seamen from ships wrecked on the southern route to Britain created here some of the greatest legends of the seas. The lure of quick fortunes from seals and whales, minerals, and the gold of the sunken General Grant have continually brought men to these islands since their first discovery.

William Bligh named the Bounty Islands after his ship, in 1785, during the famous voyage which ended in mutiny. They are little more than a collection of spray-swept granite rocks, dangerous and practically inaccessible, but during the first twenty years of the nineteenth century a number of sealing parties operated for several months at a time on the coasts. To-day they hold, in the words of Dr. F. A. Falla, " an incredible concentration of birds. Penguins in millions and mollyhawks in thousands literally cover the greater part of the surface during the summer months." 
Fur seals and sea lions are seen on the craggy snares, along with a few sea elephants, probably overflow stock from the Auckland Islands. But the main feature of the group as a nature preserve is the concentration of oceanic birds, including perhaps ten million muttonbirds which nest there. Mollyhawks and crested penguins are abundant, as are many other types of sub-Antarctic sea birds and some native land birds. The closure of these islands to sealing gangs and muttonbirders will protect the group from the introduction of rats and other animals which could ruin its rich bird life.

The Antipodes, a barren and desolate group of volcanic origin, are to-day a refuge for sea birds, and the surface of the main island appears honeycombed by the burrows of nesting birds. Albatross and skua, petrels, prions, penguins, and mollyhawks comprise the bulk of sea birds, while the green parakeet and pipit are common land birds. Sea elephants are present in small groups.

The Auckland Islands, with a substantial area of upland, have frequent prominence in the annals of the southern seas. They were the site of the Enderby whaling and fishing settlement which, with its associated farms, had a population of 200 in 1850 but was abandoned in 1852. Later attempts to establish pastoral runs failed.

In the days of the southern sailing route to Britain, many ships were wrecked against the cliffs of the mountainous Aucklands. Here the drama of the Dundonald was enacted, some of her survivors sailing to safety in a tiny coracle made of driftwood and bird skins.

Adventurers made famous the legend of the gold carried by the General Grant as she returned from the diggings. To-day the gold is regarded as probably only small in value and washed away with the erosion of the wild shores.

\section{SHEEP Station}

The Campbell Islands were first exploited as a sealing base but in 1895 they were leased as a sheep station, which continued till the recession of the 1930s. During the World War II coast watchers and weather men occupied both the Auckland and Campbell Islands but since then a meteorological station on Campbell has been the only permanent settlement in the south.

Scientists have paid considerable attention to New Zealand's subAntarctic region since World War II, particularly with the growth of interest in the far south. Expeditions have landed on all the islands, records have been made of species, and films taken of the bird life. These islands will provide a first-class breeding ground for sub-Antarctic species and, through the banning of man from these shores, stocks of birds, animals and plants will be preserved for posterity.-Dominion, Wellington.

Reproduced with the permission of Forefront, Vol. 8, No. 12, May, 1962. 